\title{
EFEKTIFITAS SENAM HAMIL PADA IBU HAMIL TRIMESTER III TERHADAP PENURUNAN NYERI PUNGGUNG DI DESA PA'RAPUNGANTA KECAMATAN POLONGBANGKENG UTARA KABUPATEN TAKALAR
}

\author{
Wirda $^{1)}$, Ernawati ${ }^{2}$ \\ ${ }^{1}$ S1 Keperawatan, STIKES Tanawali Takalar \\ Email: wirdaa8@gmail.com \\ ${ }^{2}$ S1 Keperawatan, STIKES Tanawali Takalar \\ Email: $\underline{\text { ns_erna@yahoo.com }}$
}

\begin{abstract}
Abstrack
Background: among all pregnant women, it turns out 47-60\% reported that back pain occurs in pregnancy 5-7 months and pregnancy exercises can reduce back pain in pregnant women. The aim is to find out the effects of pregnancy exercise on the reduction of back pain in Pregnant Women in Pa'rappunganta Village, Polongbangkeng Utara District, Takalar Regency. The design of this study was Quasy Experiment using a group pre-post test design approach, with a total sampling technique and the sample is 10 pregnant women with a gestational age more than 5 months, This research uses observation sheet. The results of this study indicate that the Wilcoxon test results indicate that there is an effect of pregnancy exercise on decreasing back pain in third trimester pregnant women with a value of $p=0.004<\alpha$ 0.05. Conclusion shows that there is an effect of pregnancy exercise on decreasing back pain in pregnant women in Pa'rappunganta Village, Polongbangkeng Utara District, Takalar Regency 2019.
\end{abstract}

Keywords: Pregnancy Exercise, Back Pain in Pregnant Women

\section{PENDAHULUAN}

Kehamilan yaitu suatu kejadian dimana bertemunya sel telur dengan sel sperma. Suatu kehamilan berlangsung selama kurang lebih 280 hari yang dihitung dari hari pertama periode menstruasi terkhir (Wagiyo, 2016). Kehamilan merupakan suatu pertemuan sel telur dan sel spermatozoa disertai dengan perubahan fisiologis dan psikologis. Pada suatu kehamilan sering muncul keluhan seperti:1) mual, dan muntah yang sering mucul padabulan pertama pada pagi hari dan hilang pada bulan ke ketiga. 2) Sakit pinggang: merupakan salah satu gejala yang sering muncul pada ibu hamil dikarenakan perubahan sikapbadan pindah ke depan disebabkan perut membesar. 3) Varises merupakan gejala yang sering muncul ,yang biasanya dipengaruhi oleh factor keturunan, sering berdiri lama dan usia, serta factor hormonal (progesterone). 4) sakit kepala salah satu yang sering dirasakan pada ibu hamil muda yang tidak diketahui penyebabnya. 5)Oedema merupakan pembengkakan yang biasanya terjadi pada bagian kaki dan tungkai bawah. 6) Sesak nafas merupakan salah satu yang dirasakan pada ibu hamil yang disebabkan oleh membesarnya uterus yang menekan diagfragma.

Dalam Kemenkes RI (2016) menyatakan bahwa pada proses kehamilan dapat menimbulkan beberapa perubahan pada sistem tubuh, seperti sistem muskuloskeletal dapat menyebabkan nyeri pada daerah punggung bawah pada ibu hamil.

Faktor yang dapat menyebabkan nyeri pada punggung yaitu pertumbuhan uterus yang menyebabkan perubahan postur dan bertambahnya berat badan, faktor hormon relaksin terhadap ligament, riwayat nyeri punggung sebelumnya, jumlah kehamilan dan aktivitas fisik. 
Perkembangan uterus yang sesuai dengan dengan umur kehamilan dapat mengakibatkan teregangnya ligament penopang yang sering dirasakan pada ibu hamil yang merupakan penyebab terjadinya nyeri punggung.

Angka kejadian nyeri punggung bagian bawah pada kehamilan bervariasi, berdasarkan laporan bahwa di Inggris terdapat 50\%, Australia 70\%, sedangkan di Indonesia terdapat terdapat $68 \%$ ibu hamil yang mengalami nyeri dengan intesitas nyeri punggung sedang, dan sebanyak 32\% ibu hamil dengan nyeri punggung ringan. Pada masa kehamilan nyeri punggung bervariasi 35$65 \%$. Sekitar 47-60\% ibu hamil melaporkan bahwa nyeri pungnggung biasanya terjadi pada umur kehamilan 57 bulan. Berdasarkan hasil penelitian di berbagai wilayah Indoseia terdapat 60 $80 \%$ ibu hamil yang mengalami nyei pada punggung. (Mafikasari.A \& Kartikasari.R.I, 2015).

Berdasarkan data Kementrian Kesehatan Republik Indonesia jumlah ibu hamil di Indonesia pada tahun 2016 mencapai 5.354.594 orang. Dan di Provinsi Sulawesi selatan pada tahun 2018 terdapat 1.092 orang jumlah ibu hamil.

Beberapa penelitian tentang nyeri punggung menyatakakan bahwa sekitar 25\%-90\% ibu hamil mengalami nyeri. Dan sebagaian besar penelitian memperkirakan sekitar 50\% ibu hamil yang mengalami nyeri punggung. Dengan intesnitas nyeri hebat yang dapat mempengaruhi kualitas hidup ibu hamil sekitar $80 \%$ ibu hamil melaporkan bahwa sekitar 10\% mempengaruhi kegiatan sehari-hari sampai tidak dapat bekerja.

Tingkat kejadian nyeri pinggang pada bagian bawah pada trimester I sekitar $16,7 \%$, trimester II 31,3\%, dan trimester III $53 \%$ yang akan meningkat seiring dengan pertambahan usia kehamilan (Octavia, 2018). Salah satu factor yang memperparah nyeri pada punggung yaitu backache atau yang biasa disebut dengan nyeri punggung lama, sekitar $45 \%$ wanita mengalami hal ini pada saat hamil. Dan akan meningkat sekitar $69 \%$ pada minggu ke 28 dan akan bertahan pada tingkat ini.

Untuk mengatasi nyeri pada punggung ibu hamil dapat dilakukan dengan dua cara yaitu dengan metode farmakologi dan non farmakologis. Untuk metode farmakologis dapat menggunakanan obat analgesic nonapoioid untuk mengatsai nyeri dengan skala ringan. Sedangkan untuk metode non faramkologis dapat dilakukan dengan berbagai cara seperti: teknik distraksi, hypnosis-diri, mengurangi persepsi nyeri, stimulasi masase, mandi air hangat, kompres panas atau dingin, body mekanik yang baik serta olahraga ringan (Senam Hamil). Metode non farmakologis aman diberikan pada ibu hamil karena tanpa samping, selain itu metode non farmakologi juga lebih murah (Mafikasari.A \& Kartikasari.R.I, 2015). Dalam (Octavia, 2018) juga menyatakan bahwa salah satu metode non farmakologi yang dapat dilakukan untuk menurunkan nyeri pada ibu hamil adalah senam hamil.

$$
\text { Senam hamil merupakan }
$$
aktivitas atau olahraga yang dapat dilakukan ibu hamil yang bertujuan untuk membuat otot menjadi elastis dan ligament pada panggul, selain itu senam hamil juga dapat memperbaiki sikap tubuh, mengatur kontraksi, relaksasi serta mampu meperbaiki tehnik pernafasan dan mengurangi keluhan akibat perubahan bentuk tubuh yang dapat menyebabkan nyeri.

Dalam penelitian (Rini, April 2018) dijelaskan bahwa terdapat pengaruh senam hamil terhadap penurunan rasa nyeri punggung pada ibu hamil trimester III dengan nilai $\mathrm{p}$ value $0,000 \leq \alpha \quad 0,05$. Hal tersebut sejalan dengan penelitian yang dilakukan oleh (Fitriani , November,2018) yang menyatakan bahwa terdapat penurunan 
skala nyeri pada ibu hamil sebelum dan setelah dilakukan senam hamil dengan nilai rata-rata penurunan yaitu 26 dengan nilai $p$. value 0,000 yang artinya terdapat hubungan yang bermakna.

Penelitian ini sejalan dengan penelitian yang dilakukan oleh (Mera , Maidaliza, \& Nyki, 2015) yang menyatakan bahwa terdapat perbedaan penurunan nyeri antara kelompok kontrol dan kelompok intervensi dengan nilai $\mathrm{p}$ kelompok intervensi $\mathrm{p}=0,000$ dan nilai $\mathrm{p}$ pada kelompok kontrol $=0,158$. Dan berdasarkan hasil uji statistik terdapat penurunan nyeri punggung bawah pada ibu hamil trimester II dan III dengan nilai $\mathrm{p}=0,000$. Berdasarkan beberapa hasil penelitain dapat disimpulkan bahwa tindakan non farmakologi yang efektif menurunkan nyeri pada ibu hamil adalah senam hamil.

Berdasarkan hasil wawancara yang dilakukan dengan salah satu kader kesehatan desa pa'rappunganta mengatakan bahwa senam hamil di desa pa'rappunganta tidak pernah dilakukan , dan selama ini ibu hamil di desa pa'rapunganta menganggap nyeri yang mereka rasakan adalah hal yang biasa dan wajar, dan berdasarkan hasil pengambilan data bahwa pada tahun 2019 terdapat 20 ibu hamil dan 16 oang diantaranya mengalami nyeri punggung.. berdasarkan latar belakang diatas peneti tertarik untuk melakukan peneltian bagaimana efektifitas senam hamil pada ibu hamil trimester III terhadap penurunan nyeri punggung di Desa pa'rappunganta kecamatan Polongbangkeng Selatan kabupaten Takalar.

\section{METODE}

Dalam penelitian ini Desain yang digunakan adalah Quasy Eksperiment dengan menggunakan pendekatan one group pre-post test design, yang bertujuan untuk melihat bagamana efektifitas senam hamil terhadap penurunan nyeri punggung pada ibu hamil trimester III. Pengukuran pada penelitian ini terdapat dua kelompok yakni kelompok observasi sebelum dilakukan intervensi kemudian diobservasi lagi setelah dilakukan intervensi. Tehnik pengambilan sampel pada penelitian ini yaitu Total Sampling, sampel dalam penelitian ini adalah ibu hamil trimester III di Desa Pa'rappunganta kecamatan Polongbangkeng Utara Kabupaten Takalar sebanyak $10 \mathrm{ibu}$ hamil. Untuk mengukur nyeri alat yang digunakan berupa lembar observasi nyeri punggung pada ibu hamil sebelum dan sesudah dilakukan intervensi. Uji yang digunakan dalam penelitian ini adalah uji Wilcoxon.

\section{HASIL DAN PEMBAHASAN}

\section{HASIL}

a. Distribusi Karakteristik Responden

Tabel 1. Distribusi Karakteristik Responden berdasarkan umur

\begin{tabular}{lcc}
\hline $\begin{array}{c}\text { Karakteristik } \\
\text { responden }\end{array}$ & $\begin{array}{c}\text { Mean } \\
(\mathbf{m i n}- \\
\text { max })\end{array}$ & SD \\
& $\begin{array}{c}26,0 \\
(18-33)\end{array}$ & $\pm 4,496$ \\
Umur & $\mathbf{N}$ & $\%$ \\
$\begin{array}{c}\text { Karakteristik } \\
\text { Responden }\end{array}$ & & \\
\cline { 1 - 1 } $\begin{array}{c}\text { Usia : } \\
\text { 20 kebawah dan }\end{array}$ & 1 & 10,0 \\
$\begin{array}{c}35 \text { tahun keatas } \\
\text { 20-35 tahun }\end{array}$ & 9 & 90,0 \\
\hline \multicolumn{1}{c}{ Jumlah } & 10 & 100 \\
\hline
\end{tabular}

Berdasarkan Tabel 1 di atas dapat dilihat bahwa dari 10 responden, rata-rata responden berumur 26 tahun.

Tabel 2. Distribusi karakteristik responden berdasarkan usia kehamilan dan paritas

\begin{tabular}{|c|c|c|}
\hline $\begin{array}{c}\text { Karakteristik } \\
\text { Responden }\end{array}$ & $\mathbf{n}$ & $\%$ \\
\hline \multicolumn{3}{|l|}{ Umur Kehamilan } \\
\hline Trimester I & 7 & 70,0 \\
\hline Trimester II & 3 & 30,0 \\
\hline \multicolumn{3}{|l|}{ aritas } \\
\hline $1-3$ & 9 & 90,0 \\
\hline$>3$ & 1 & 10,0 \\
\hline Jumlah & 10 & 100 \\
\hline
\end{tabular}


Pada Tabel 2. Dapat dilihat dari 10 responden mayoritas responden memiliki usia kehamilan 4-6 bulan $(70,0 \%)$, dan mayoritas responden memiliki paritas 1-3 $(90,0 \%)$.

Tabel 3. Karakteristik Responden berdasarkan pekerjaan dan pendidikan

\begin{tabular}{lcc}
$\begin{array}{l}\text { Karakteristik } \\
\text { Responden }\end{array}$ & $\mathbf{n}$ & $\boldsymbol{\%}$ \\
\cline { 1 - 1 } $\begin{array}{l}\text { ekerjaan } \\
\text { IRT }\end{array}$ & & \\
Honorer & & 90,0 \\
Pendidikan & & 10,0 \\
SD & 3 & 30,0 \\
SMP & 3 & 30,0 \\
SMA & 3 & 30,0 \\
Diploma/Sarjana & 1 & 10,0 \\
\hline \multicolumn{1}{c}{ Jumlah } & 10 & 100 \\
\hline
\end{tabular}

Berdasarkan hasil Tabel 3. Dapat disimpulkan bahwa sebagian besar memiliki pekerjaan bekerja sebagai IRT $(90,0 \%)$ dan pendidikannya hanya $10 \%$ yang Sarjana, selebihnya adalah SD, SMP , dan SMA masing-masing sebesar $30 \%$.

b. Distribusi Tingkat Nyeri Sebelum Senam Hamil

Tabel 4. Distribusi Tingkat Nyeri SebelumSenam Hamil

\begin{tabular}{ccc} 
Skala Nyeri & N & $\mathbf{\%}$ \\
\hline Ringan & 0 & 0 \\
Sedang & 8 & 80,0 \\
Berat & 2 & 20,0 \\
\hline Jumlah & 10 & 100 \\
\hline
\end{tabular}

Berdasarkan dari Tabel 4.

Dapat dilihat dari 10 jumlah sampel, yang diberikan kegiatan senam hamil mayoritas responden mengalami tingkat nyeri sedang dengan jumlah 8 orang $(80,0 \%)$ dan selebihnya adalah responden dengan nyeri berat yaitu sebanyak 2 orang $(20,0 \%)$.

c. Distribusi Skala Nyeri Setelah Senam Hamil
Tabel 5. Distribusi Skala Nyeri Setelah Senam Hamil

\begin{tabular}{ccc}
\hline Skala Nyeri & N & \% \\
\hline Nyeri Ringan & 6 & 60,0 \\
Nyeri Sedang & 4 & 40,0 \\
Nyeri Berat & 0 & 0 \\
\hline Jumlah & 10 & 100 \\
\hline
\end{tabular}

Tabel 5 di atas menunjukan bahwa dari 10 responden, setelah dilakukan senam hamil kebanyakan responden mengatakan mengalami tingkat nyeri ringan yaitu 6 responden $(60,0 \%)$ dan selebihnya adalah responden dengan nyeri sedang yaitu 4 (empat) responden $(40,0 \%)$.

d. Analisa Bivariat

Tabel 6. Analisis Perbedaan Skala Nyeri Punggung Sebelum DanSetelah Senam Hamil Di Desa Pa'rappunganta Kecamatan Polongbangkeng Utara Kabupaten Takalar

\begin{tabular}{ccccc}
\hline $\begin{array}{c}\text { Skala } \\
\text { Nyeri }\end{array}$ & Mean & $\begin{array}{c}\text { Min- } \\
\text { Max }\end{array}$ & SD & P \\
\cline { 1 - 3 } Pre & 5,80 & $4-8$ & $\pm 1,135$ & 0.004 \\
Post & 3,10 & $2-5$ & $\pm 1,287$ & \\
\hline
\end{tabular}

* Uji Wilcoxon , 10 skala nyerinya menurun, 0 meningkat, dan 0 yang tetap

Table 6 di atas menyajikan data perbedaan tingkat nyeri punggung antara pre dan post senam hamil pada ibu hamil di Desa Pa'rappunganta Kecamatan Polongbangkeng Utara Kabupaten Takalar, dimana intensitas nyeri sebelum senam lebih tinggi yaitu 5,80 $( \pm 1,135)$ dan intensitas nyeri berkurang setelah senam menjadi $3,10( \pm 1,287)$.

Uji statistic yang digunakan adalah uji wilcoxon, dan berdasarkan hasil uji diperoleh semua responden mengalami perubahan yaitu tingkat nyeri punggung 
menurun dengan nilai $\mathrm{p}=0,004<\alpha 0,05$. Hal ini dapat dilihat bahwa dari hasil secara statistic didapatkan hasil bahwa senam hamil dapat mempengaruhi penurunan nyeri punggung pada ibu hamil di Desa Pa'rappunganta Kecamatan Polongbangkeng Utara Kabupaten Takalar.

\section{PEMBAHASAN}

Berdasarkan hasil dari table 4 dapat dilihat bahwa dari 10 responden sebelum diberikan perlakuan senam hamil hampir seluruh responden mengalami nyeri sedang yaitu sebanyak 8 orang $(80,0 \%)$ dan selebihnya adalah responden dengan nyeri berat yaitu sebanyak 2 orang $(20,0 \%)$.

Nyeri adalah perasaan tidak nyaman yang dirasakan pada bagian tempat tertentu di salah satu bagian tubuh. Banyak hal yang dapat mempengengaruhi terjadinya nyeri punggung pada ibu hamil, salah satunya adalah perubahan bentuk tubuh yang biasanya dipengaruhi oleh adanya perubahan berat badan, semakin tua usia kehamilan perutpun semakin membesar yang menyebabkan peregangan otot perut lemah dan hal ini dapat menyebabkan lekukang pada tulang belakang. Selain itu pekerjaan sehari - hari seperti kegiatan pekerjaan rumah tangga yang biasanya dilakukan dengan duduk selama kehamilan tua dilakukan dengan berdiri dalam waktu yang cukup lama. (Wagiyo \& Putrono, 2016).

Berdasarkan hasil pengolahan data pada tabel 6 menyajikan data perbedaan skala nyeri punggung antara sebelum dan setelah dilakukan senam hamil pada ibu hamil di Desa Pa'rappunganta Kecamatan Polongbangkeng Utara Kabupaten Takalar, dimana intensitas nyeri sebelum senam adalah 5,80 $( \pm 1,135)$ dan menurun

menjadi menjadi 3,10 $( \pm 1,287)$ setelah senam.

Berdasarkan hasil penelitian ini dapat disimpulkan bahwa senam hamil dapat mempengaruhi nyeri pada punggung karena dengan melakukan senam hamil otot bias lebih elastic terutama pada bagian otot dinding perut, ligamen, serta otot pada dasar panggul sehingga akan memberikan rasa nyaman dan lebih rileks pada Ibu hamil. Disamping itu gerakan yang dilakukan pada saat senam dapat membuat otot pantat lebih kencang, otot perut dan bahu sehingga nyeri punggung yang dirasakan saat hamil jadi berkurang.

Dengan melakukan gerakan senam hamil dapat melatih otot perut bagian dalam yang yang memiliki fungsi utama sebagai penopang tulang punggung. Demikian pula pada gerakan dibagian otot pelvis karena dengan gerakan tersebut dapat menjadikan tonus otot lebih kuat serta meningkatkan ketahanan otot postural yang terletak pada dasar pelvis. Disamping itu dengan melakukan aktivitas senam hamil secara rutin dan teratur sangat bermanfaat untuk memperkuat otot-otot perut serta mencegah terjadinya ketegangan pada pelvis yang berlebihan sehingga mengurangi rasa tidak nyaman serta nyeri pada punggung. Kegiatan senam hamil juga mampu mengeluarkan endorphin yang berfungsi untuk memberikan rasa tenang sehingga bisa mengurangi rasa tidak nyaman dan nyeri pada punggung saat hamil.

Penelitian yang dilakukan oleh Rini (2018), diperoleh hasil senam hamil dapat mempengaruhi penurunan intensitas nyeri punggung pada ibu hamil di usia kehamilan tuju bulan ke atas. Selain itu peneliti lain yang dilakukan oleh Megasari (2015), di Rumah Brsalin Fatmawati didapatkan bahwa perbandingan antara yang melakukan senam hamil dan tidak melakukan senam hamil memiliki perbedaan yaitu 21 (100\%) responden melakukan senam hamil tidak merasakan adanya nyeri punggung, sedangkan 26 responden lainnya tidak diberikan kegiatan senam hamil didperoleh $16 \quad(61,5 \%)$ responden diantaranya mengalami nyeri punggung dengan nilai statistic $\mathrm{p}=0,000<$ dari nilai alfa $(0,05)$, hasil ini membuktikan bahwa senam hamil memilliki nilai signifikansi terhadap penurunan nyeri punggung. Dalam penelitiannya, Fitriani 
(2018), juga diperoleh hasil bahwa intensitas nyeri menjadi berkurang setelah dilakukan senam hamil dengan nilai p.value 0,000 yang artinya ada hubungan yang signifikan antara penurunan intensitas nyeri punggung pada ibu yang melakukan senam hamil. Demikian halnya dengan penelitian yang dilakukan oleh Firdayanti (2018), didapatkan hasil nilai statistic dengan menggunakan uji Spearmen Rank $\mathrm{p}=0,000<$ alfa 0,05 yang menunjukkan bahwa Hipotesis I diterima yakni ada pengaruh antara senam hamil dengan berkurangnya intensitas nyeri pada ibu hamil di usia kehamilan enam bulan ke atas. Penelitian lain yang dilakukan oleh Mera, dkk (2018), diperoleh nilai $\mathrm{p}=0,000$ pada kelompok perlakuan sedangkan pada kelompok control didapatkan nilai $\mathrm{p}=0,158$, hal ini menunjukkan bahwa ada perbadaan yang siginifikan antara kelompok perlakuan dengan kelompok control terhadap penurunan nyeri. Penelitian ini menggunakan uji statistic Paired t-Test dengan tingkat kepercayaan $95 \%$ nilai $\mathrm{p}=0,000$ dengan nilai $\mathrm{f}=44,755$.

Berdasarkan hasil penelitian yang dapat disimpulkan bahwa senam hamil sangat efektif untuk menurunkan nyeri punggung pada ibu hamil di Desa pa'rappunganta Kecamatan Polongbangkeng Utara Kabupaten Takalar. Oleh karena itu sangat direkomendasikan dan dianjurkan untuk ibu hamil baik yang dengan kehamilan pertama ataupun ibu multigravida untuk mengikuti program kegiatan SENAM IBU HAMIL

\section{KESIMPULAN}

Hasil penelitian yang dilakukan di Desa Pa'rappunganta Kecamatan Polongbangkeng Utara Kabupaten Takalar tentang Efektivitas senam hamil terhadap penurunan nyeri punggung pada ibu hamil, maka peneliti dapat menarik kesimpulan :

1. Hasil penelitian dari 10 responden, yaitu sebelum dilakukan senam hamil didapatkan rata-rata skala nyeri yaitu $5,80( \pm 1,135)$
2. Hasil penelitian dari 10 responden, yaitu setelah senam hamil rata-ratanya menurun menjadi 3,10 ( $\pm 1,287)$

3. Adanya Efektifitas Senam Hamil terhadap penurunan intensitas nyeri punggung pada ibu hamil di Desa Parapunganta Kecamatan Polongbangkeng Utara Kabupaten Takalar Tahun 2019dengan nilai $\mathrm{p}=0,004<\alpha 0,05$

\section{REFERENSI}

Devi, M., Sulaiman, R., \& Jawiah.(2014). Pengaruh Yoga Antenatal Terhadap Pengurangan Keluhan Ibu Hamil Trimester III. Jurnal Kesehatan\& Kedokteran. Vol.1 No.1, Hal. 47-5

Fitriani, L.(2018). Efektifitas senam hamil dan yoga hamil terhadap penurunan nyeri punggung pada Ibu hamil trimester III di PKM Pekabata. Jurnal Kesehatan Masyarakat, Hal.87-95

Fraser, \& Cooper.(2011). Buku ajar Bidan Myles. Jakarta: EGC.

Hidayat, A.A.(2018). Metodologi Penelitian keperawatan dan Kesehatan. Jakarta : Salemba Medika.

Inding, I.(2016). Pengaruh senam hamil terhadap perubahan derajat nyeri pada Ibu hamil yang menderita nyeri pinggang bawah. Skripsi. Fakultas kedokteran Univeritas Hasanuddin Makassar.

Kemenkes, R.I.(2016). Panduan teknis latihan fisik selama kehamilan dan nifas. Jakarta: Kemenkes RI.

Lebang, \& Elizabeth.(2015). Yoga atas Backpain. Jakarta: Pustaka Bunda

Lobo, Y., Luni, T.Y.(2014). Mekanisme nyeri. Kupang: Stikes Citra Husada Mandiri Kupang.

Mafiksari, A. \& Kartikasari, R.I.(2015). Posisi tidur dengan kejadian Backpain pada Ibu hamil trimester III, Hal.1-8 
Manuaba, I.,B.,G.(2010). Gawat darurat obstetric ginekologi dan Obstetri ginekologi social Untuk profesi Bidan. Jakarta: EGC.

Maidaliza, M.,D.(2015). Pengaruh senam hamil terhadap penurunan tingkat nyeri punggung bawah pada Ibu hamil trimester II \& III di PKM Parit Rantang Payakambuh.

Megasari.(2015). Hubungan senam hamil dengan Nyeri punggung pada Ibu hamil trimester III di RSB Fatmawati

Moffat, S.,M.(2011). Panduan praktik mahasiswa kebidanan. Jakarta: EGC

Nursalam.(2017). Metodologi penelitian ilmu keperawatan pendekatan praktis, Edisi 4. Jakarta: Salemba Medika

Nurhudayaeni.(2017).Model prediksi berat lahir bayi berdasarkan berat badan Ibu sebelum hamil dan pertambahan berat badan pertrimester

Octavia, A.,M.(2018). Pengaruh senam yoga terhadap penurunan nyeri punggung pada Ibu hamil trimester III. Jombang: Cendekia Medika.

Potter, \& Perry.(2010). Fundamental of Nursing:Fundamental keperawatanBuku 3 Edisi 7. Jakarta: EGC

Rini, A.(2018). Pengaruh senam hamil terhadap penurunan rasa nyeri punggung pada Ibu hamil trimester III.

Romauli, \& Suryanti.(2011). Asuhan kebidanan konsep dasar: Asuhan Kehamilan. Yogyakarta: Nuha Medika

Robson, Jason, W., Elizabeth, S.(2012). Patologi pada kehamilan. Jakarta: EGC

Nety, R.,R., Ira K..(2016). Korelasi perubahan psikologis Ibu hamil dengan tingkat kepuasan seksual suami. Jurnal Bidan
Sartika, \& Nita.(2016). Asuhan kebidanan fisiologis.Ciamis : STIKES Muhammadiyah

Sinclair.(2010). Buku saku kebidanan. Jakarta: EGC

Wagiyo, \& Putrono.(2016). Asuhan keperawatan antenatal, intranatal dan bayi baru lahir fisiologis dan patologis. Yogyakarta: CV Andi

Wagey.(2011). Senam hamil meningkatkan antioksidan Enzimatik, kekuatan otot panggul, kualitas jasmani, dan menurunkan kerusakan oksidasi pada wanita hamil. Jakarta: EGC

Widianti,A.,T \& Proverawati.(2010) Senam kesehatan. Yogyakarta: Nuha Medika 